\title{
Las Fronteras Antioqueñas: Los Desencuentros de las Élites Montaraces y el Pueblo Calentano
}

\author{
Por: Margarita Rosa Díaz Benjumea
}

\section{RESUMEN}

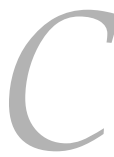

on posterioridad a la primera mitad de siglo XIX, algunos sectores hegemónicos de la sociedad asentada en la región que en la Colombia de entonces correspondía a la provincia antioqueña, fueron concentrando cada vez su interés en la construcción de un modelo de hombre antioqueño caracterizado por sus "buenas costumbres" y virtudes públicas y privadas, y, sobre todo, por su vocación por el propio progreso económico y material.. Ese ideal, aunque era más expresión de motivaciones propias de las clases altas y de los gobernantes regionales, fue promulgado y propuesto como obligante para el resto de los pobladores. Ello fue más evidente en algunos contextos micro regionales en donde la respectiva dirigencia política logró promover y llevar adelante obras públicas, que por su magnitud y significación fueron percibidas por ésta como enaltecedoras del "hombre antioqueño". Uno de ellas fue la construcción del Ferrocarril de Antioquia, obra que se llevó a cabo con la supervisión de algunos "magnánimos hombres de bien" antioqueños, a través de la región del Magdalena Medio, y, en este caso específicamente, en la región conocida como "Nus" pasando desde Medellín hacia dicha zona por el Alto de la Quiebra. Ella estaba conformada desde el actual municipio de El Limón hasta Puerto Berrío.

Con lo que no contaron estos hombre de bien fue con que, en un territorio que hasta entonces no había sido de interés para la política del gobierno estadual, habitado por hombres y mujeres cuya vida cotidiana había sido configurada sin la prevalencia de lo valores recién propuestos, no se iban a acoger con docilidad a este modelo de "buenas costumbres", más propios de la "buena sociedad" de la capital del Estado, Medellín.

Este encuentro entre las clases dirigentes capitalinas y los habitantes del Magdalena Medio generó una serie de conflictos que llevaron a que las élites antioqueñas ("los establecidos"), buscaran a toda costa poner freno a la forma de vida de los habitantes de aquella región (los marginados), con el fin de "educarlos y hacerlos hombres de bien", bajo las leyes y enseñanzas que Dios y los políticos antioqueños determinaban. 


\section{Introducción}

Durante el siglo XIX en Antioquia, estar por fuera de ciertos parámetros elitarios, como ser blanco, católico y respetuoso de las normas sociales, convirtió a los habitantes de las zonas aisladas en un problema social, en la medida en que se constituían en un obstáculo para todo proyecto de homogenización regionalista del Estado. Con este reto, algunos sectores de las élites proyectaron y llevaron a cabo un proceso de control social que subsanara las diferencias entre las regiones e hiciera la unificación social y cultural del Estado antioqueño.

Se promovieron activamente, entonces, sistemas de interacción social que, de darse entre los sujetos involucrados, legitimarían y harían efectiva aquellas rígidas relaciones de dominación entre controladores y controlados que se proponía instaurar. Un sistema relacional que se reconstituiría a través de la intromisión dominante de los primeros en la vida de los segundos, y que se haría efectivo en todos los ámbitos de la vida de los segundos, en sus formas de vivir cotidiano, de sus procesos productivos, comportamiento político, y hasta en los resquicios más íntimos de la vida familiar y personal de los individuos.

"Todo proyecto de dominación nunca es gratuito; la imposición de concretos intereses sociales para el conjunto de una sociedad no puede alcanzarse sino es a través de lograr una persuasión de que ellos son los mejores para la mayoría. Para lo cual, es evidente, resulta necesario convencer, persuadir, infundir en el ánimo de los destinatarios de que mantener un determinado orden social es la manera adecuada para lograr que el predominio de esos intereses produzca el beneficioso resultado prometido. Naturalmente, si el convencimiento, la persuasión o la aceptación de este orden resultan inalcanzables, ya estarán entonces prestos otros recursos más efectivos para obtener, ahora sí, el sometimiento." (Bergalli, R. y Mai, E., 1989: p. III).

En este sentido, los capitalinos se propusieron ejercer un profundo control social en la región por donde correría el trazado del ferrocarril, a través de una estrategia específica de proyección autoritaria de sus parámetros de comportamiento y costumbres, es decir, desde su "cultura". Ésta fue utilizada tanto a manera de coacción desde el exterior del sistema cultural de los habitantes de la zona a recolonizar, como a través de la inducción en éstos de procesos de introyección y autocoacción de los elementos de la cultura de los capitalinos empresarios, procesos complementarios que garantizarían el predominio y acatamiento público y privado del sistema de normas y valoraciones que intentaban las élites instaurar entre los habitantes del Magdalena Medio antioqueño. En este último entendido, el proyecto hegemónico de las élites medellinense puede bien entenderse 
en términos planteados por Elías, es decir, como "[...] la modelación de los individuos [con el fin] de convertir el comportamiento social deseado en un automatismo, en una autocoacción, para hacerlo aparecer como un comportamiento derecho en la conciencia del individuo, como algo que tiene su origen en un impulso propio en pro de su propio salud o de su dignidad humana" (Elías, N. 1998: 82 - 83 p).

Esta normatividad y taxonomía social contrapuso a unos grupos contra otros y determinó una continua conflictualidad entre quienes Norbert Elías llamaría, por una parte, los establecidos (las élites de Medellín), y, por la otra, los marginales (los habitantes del Nus). Los primeros tenían el poder y el prestigio, y los segundos carecían de este y eran desdeñados éstos. Se planteó entonces una situación caracterizada por Elías cuando afirma que "En todos los casos, el grupo más poderoso se ve así mismo como gente 'mejor', como dotado de una especie de carisma de grupo, como poseedor de un valor que comparten todos sus miembros mientras otros carecen de él. Es más, en todos estos casos la gente 'superior' puede lograr que la gente menos poderosa se sienta como si le faltasen valores, es decir, como si fuese humanamente inferior «(Elías, N. 1998: 82-83 p).

Los marginales se llegarían a convertir de esta manera en una especie de clase no bañada -término usado en Inglaterra durante el proceso de industrialización-, expresión que remite a aquellos grupos que se encuentran por fuera de las reglas, que no siguen las buenas costumbres y que son perjudiciales para el bien común. Esta idea de los no bañados encierra, por supuesto, una definición manipulativa del Otro a partir de los propios parámetros de la contraposición entendida por éstos como dicotomía entre civilización e incivilización.

En este punto, echamos mano nuevamente de Elías, cuando reconstruye históricamente el concepto burgués de "civilización", entendido entonces como:

"todo aquello que la sociedad Occidental de los últimos dos o tres siglos cree llevar de ventaja a las sociedades anteriores o a las contemporáneas 'más primitivas'. Con este término 'civilización' trata la Sociedad occidental de caracterizar aquello que expresa su peculiaridad y de lo que se siente orgullosa: el grado alcanzado por su técnica, sus modales, el desarrollo de sus conocimientos científicos, su concepción de mundo y muchas otras cosas" (Elías; N. 1987: 57 p).

Este sentido eurocéntrico de "civilización" debe su importancia a que, a través de su adaptación y apropiación particular, los grupos dominantes herederos de 
las coloniales sociedades euroamericanas expresaron también su idea de desarrollo, progreso y perfección. En este sentido, los grupos dominantes antioqueños, sobre todos los que en el siglo XIX consolidaban su posición privilegiada en la capital del Estado de Antioquia, hicieron valer su percepción de que el mundo situado por fuera de su experiencia de vida, $y$, por tanto, toda expresión que riñera con su homogeneizante criterio, fuera catalogado de inmediato como incivilizado, como sinónimo de lo atrasado y de lo bárbaro y que por tanto debería erradicarse para crear una Antioquia moderna, progresista, educada, sana en cuerpo y espíritu, higiénica y de buenas costumbres, capaz de ocupar un lugar entre los pueblos cultos del planeta. Es importante destacar la concepción, al tiempo, "cosmopolita" y provinciana de las élites antioqueñas para las cuales era garantía de civilización y progreso, así como estrategia para alcanzarlos, la apertura y el vínculo con un "exterior" (europeo) idealizado.

\section{Antioquia en el Siglo XIX: La Consolidación de una Forma de Ser}

Para principios de la década de los años sesenta del Siglo XIX, Antioquia había logrado consolidar, en el concierto nacional colombiano, una identidad propia basada en la diferencia, es decir, en ciertas rasgos sociales y culturales exclusivos de los habitantes de ese territorio, los que se creía no poseían las gentes de las otras regiones del país. El antioqueño había construido las bases de una imagen de si mismo que lo hacia verse no sólo diferente sino, sobre todo, superior a los demás. En buena parte, esta elevada autoestima se generó debido a su lucha de siglos para sortear las difíciles condiciones territoriales y ambientales del medio que habitaban; el antioqueño se consideraba vencedor de la dura lucha entre el hombre y la naturaleza, sobreviviente exitoso que logra crear una sociedad civilizada y una organización política auténticamente republicana en medio de duras montañas e impenetrables y fangosas selvas milenarias.

"La población antioqueña es incuestionablemente la más vigorosa, emprendedora y enérgica [...] una población débil y raquítica habría sucumbido delante de esa naturaleza recalcitrante. Pero al antioqueño no lo han arredrado las dificultades de la comarca arrugada que le tocó en lote. Ha construido habitaciones sobre picachos tan elevados, que allí les daría vértigo a las águilas; a través de las faldas casi perpendiculares ha hecho caminos, ha cultivado valles insalubres $y$ mortíferos, y, en busca del oro, ha horadado las cordilleras y bajado con los ojos abiertos al fondo de los ríos". (Kastos, E. 1972: 307 p)

Desde finales de la colonia, y sobre todo a partir de los inicios del período republicano, esta idea de superioridad se fue sustentando en el hecho de asumirse 
como vigorosos hombres vencedores de la adversidad y de las montañas, y se fue introyectando progresivamente en sus habitantes. Los antioqueños iniciaron una carrera por ser los mejores, los más destacados y reconocidos en el concierto multirregional colombiano. Se caracterizaron a sí mismos de manera integral, incluyendo tanto los rasgos referidos a la parte física cómo a las valoraciones e imágenes culturales del ser y del deber ser de un antioqueño. El antioqueño era aquél personaje que usaba ponchos y alpargatas, que tomaba aguardiente, comía mazamorra y frijoles, mientras iba sin desfallecimiento alguno civilizando la selva, abriendo camino a la civilización y el progreso. Su entusiasmo por destacarse contribuyó a hacer de ellos excelentes trabajadores, emprendedores e imaginativos agentes económicos y colonizadores expansionistas que no desaprovechaban ninguna posibilidad de hacerse a nuevas tierras y nuevas fuentes de riqueza.

Los antioqueños poseían unos "rasgos vigorosos [que hacían parte] de su peculiar idiosincrasia o sicología, el comportamiento del antioqueño como individuo y de los antioqueños como colectividad, sus realizaciones -verdaderamente positivas- en el campo de la cultura del espíritu y de la civilización material, todos estos elementos de la personalidad antioqueña son tan nítidos y acusados, que los estudios colombianos y también extranjeros, a modo de ver o meditar caen en la cuenta de que se hallan ante un caso no sólo interesante sino muy importante dentro del terreno histórico, del geográfico o sociológico de Colombia" (Bravo, J.M. 1993: 42 p).

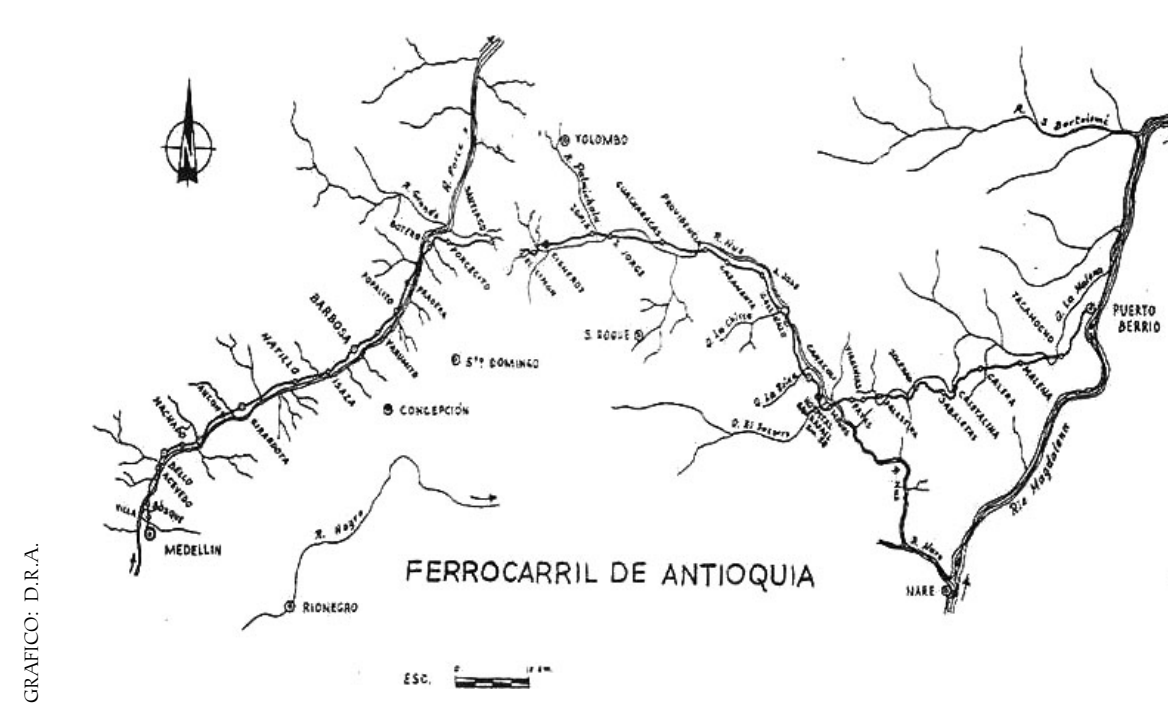

Esta autopercepción de ser antioqueño, así como la caracterización que de éste hacían los extranjeros y los habitantes de otros Estados colombianos no era gratuita, puesto que, como ya se mencionó, ella había sido cuidadosamente elaborada por grupos elitarios de la sociedad, por miembros de la clase dirigente, gobernantes, la Iglesia católica y del Estado. Pero en principio no tuvieron mucho que ver, al menos en las fases iniciales de la aculturación de clase que se desplegó a partir del Siglo XIX, con la propia percepción que los pobladores comunes y 
corrientes del Estado se hacían de sus propias formas de vivir de y sentir. Sin embargo, una lenta pero progresivamente exitosa tarea de propaganda, persuasión e imposición logró el objetivo de las élites urgidas por la utilitaria necesidad de homogeneizar a sus pobladores bajo un conjunto básico de costumbres e ideologías relativamente uniformes (teniendo como criterios de unificación a las propias), en particular en lo atinente a la valoración eminente de sus objetivos de laboriosidad, priorización del desarrollo material, y por ese camino, del desarrollo , así como la incesante búsqueda incesante de nuevos escenarios de oportunidades y posibilidades conducentes, en el marco de este mismo sistema ideológico, a la "felicidad" de sus gentes, y al lugar de avanzada en la jerarquía de las regiones colombianas.

Vale la pena señalar, que en relación con este ideal, fue tal vez en lo único en que los partidos liberal y conservador antioqueños nunca estuvieron en desacuerdo, no importando en este caso las divergencias que sí se daban en otros campos de los avatares partidistas y en las formas de gobernar. Todos estaban tan seguros de lo que querían de su Estado y de su gente, e independientemente de quién estuviera en el poder, no hacían nada que pudiera entorpecer el cumplimiento de las metas de desarrollo y progreso, pensados, como vimos, no tanto en términos de encuentro cultural o de desarrollo integral de la población, sino como mejoramiento material e incremento monetario de sus actores sociales, es decir, entre otras cosas, como desarrollo de las vías de comunicación, de la industria, del comercio, en fin, como desarrollo empresarial. Y este sentir fue pasando, como lo afirma Ann Twinam (1985: 241 p), de un "modo de estar" a un "modo de ser" que en adelante determinaría y diferenciaría a un antioqueño en cualquier lugar.

Pero este progreso necesitaba de un buen número de esfuerzos, ya que la siembra de café y la ganadería incrementaron, después de la primera mitad del Siglo XIX, su producción agregando otro condicionante económico a la "necesidad urgente de romper la clausura y aislamiento en que mantenían a Antioquia las desfavorables condiciones geográficas de su territorio,[que] venían preocupando a todos sus habitantes, que sentían, más o menos consciente, embarazado el progreso y anuladas sus iniciativas industriales por tan formidables barreras. Deseábase ahincadamente la rápida y barata salida a un río navegable, para acercarnos a otras regiones del país con las cuales pudiéramos tener mayor intercambio y para hacer menos demorada y difícil nuestra comunicación con el exterior, que era entonces lenta y pesada" (Escobar, E. 1975: 45 p).

Además, porque para figurar en el mercado mundial, que era la pretensión de las 
élites del Estado, se imponía satisfacer una serie de condicionantes que tenían que ver con el desarrollo vial y manufacturero, lo que hacía imprescindible la construcción de nuevos puertos, pueblos, casas mercantiles, bancos y caminos de diversas índoles para poder negociar, comprar y vender productos de toda clase. Materias primas, especialmente, metales preciosos, madera y productos naturales fueron cada vez más la materia de los intercambiados por telas, lencería, máquinas, entre otros bienes. Los antioqueños querían ser el ejemplo a seguir en América, ya que, pensaban, "sólo los pueblos superiores se expandían y le enseñaban a los demás los frutos de la civilización. Así como Europa lo hizo con América [...] Antioquia debería tomar el relevo..."(Peralta, J. 1998: 43 p), entre los Estados colombianos.

Era, por tanto, indispensable abrir caminos y vías de comunicación que permitieran el tránsito eficiente de entrada y salida del Estado, ya que los pocos que habían, "[...] eran sinuosos y de difícil tránsito durante buena parte del año. Lo que obstaculizaba los desplazamiento, las comunicaciones y las operaciones comerciales de sus habitantes [...]" (Jurado, J.C. 1999: 1 p). Los nuevos caminos proyectados deberían privilegiar las rutas hacia los centros de consumo y hacia los ríos, en cuyas riberas se construirían puertos. Así se podría asegurar un verdadero librecambio de mercancías entre Antioquia y los mercados internacionales, aspiración primera del empresariado antioqueño. Además, los caminos harían asequibles las zonas más distantes y los lugares más recónditos del Estado para lograr la integración de toda la región antioqueña, erigiéndose, a la vez, a la vera de los nuevos caminos abiertos, nuevos poblados de hombres de trabajo que terminarían de descuajar las selvas y abrirlas al poblamiento de gentes de bien, con civilizadores "montaraces", como las élites antioqueñas se nombraban así mismas para diferenciarse de los habitantes de otras regiones, especialmente de las cálidas, donde se suponía habitaban los incultos y bárbaros.

Se destaca en este artículo un hecho particular en relación con el proceso de despliegue y arraigo de la versión hegemónica de lo que era ser auténtico antioqueño, auspiciada por las élites de la región, en particular de las que se iban asentando a lo largo del siglo XIX en el Valle de Aburrá, en la ciudad de Medellín, se trata de la confrontación, simbólica y práctica de dos subregiones antioqueñas: Medellín - El Nus.

Hasta mediados del Siglo XIX, el empresariado de Medellín no se había percatado realmente de que al interior del territorio antioqueño también existían zonas cálidas como esa, que tenían las mismas características ambientales y sociales que ellos denigraban de otras regiones colombianas. La evidencia de este hecho 
los enfrentó al dilema de como abrir caminos y expandir el ideal del ser antioqueño a lugares tan inhóspitos y malsanos y a habitantes tan incivilizados como la tierra que vivían, pero sobre todo, como lograr que ellos no contaminaran los sanos ideales colectivos propuestos y difundidos desde Medellín para el favor y la grandeza de la tierra antioqueña.

El asunto no era sencillo. Las fronteras hasta entonces impuestas por la naturaleza y la civilización entre "montaraces" y "calentanos", estaban por difuminarse con la construcción del Ferrocarril y las consecuencias de estos nuevos vínculos no se podrían determinar a priori por ninguno de los actores del proceso. Caracterizamos mejor este proceso, en palabras de F. Ainsa:

“El límite, en tanto que línea trazada en forma simbólica o real, instaura un orden que no es únicamente de naturaleza espacial -la frontera que separa el 'aquí' del allá, lo que encierra en su perímetro y lo que excluye- sino algo mucho más complejo, ya que las fronteras geográficas y políticas conforman en buena parte las fronteras sicológicas de sus habitantes. Creencias, prejuicios, estereotipos, tópicos, imágenes y símbolos, variantes lingüísticas, prosperan al socaire de fronteras que, aún tildadas de artificiales, legitiman diversas expresiones [...]" (Ainsa, F. 2000: 46 p).

Justamente, a esa diversidad de visiones y de formas de vida era a lo que temían las élites de Medellín, pues consideraban que (lo que ellos asumían ser) los antioqueños, no obstante todas las disensiones y conflictos vividos y sufridos en los años de surgimiento y consolidación como Estado, se caracterizaba por su unicidad y por su homogeneidad, circunstancia que se podría ver peligrosamente afectada por el cruce y el

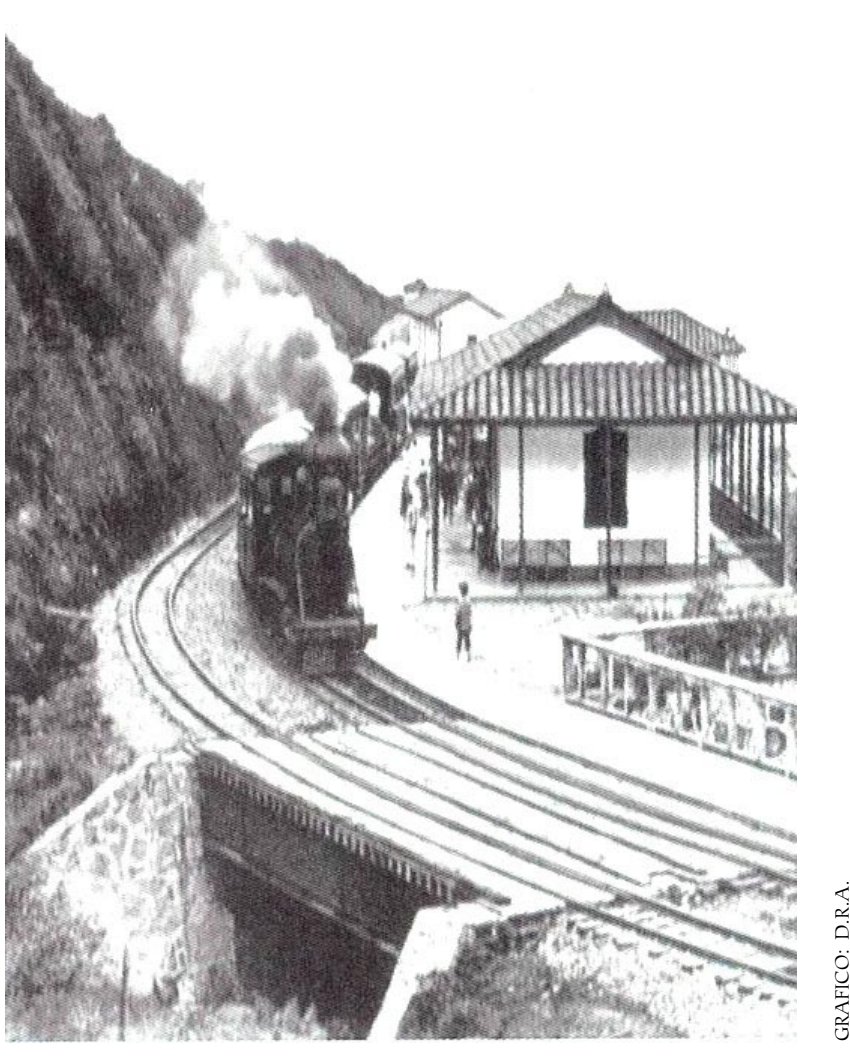
rebasamiento del límite, de las fronteras.

El cruce obligado, por obra de los avances de la obra del Ferrocarril en la zona del Nus, de ese límite socioespacial, de esa frontera entendida aquí como el conjunto de "actos selectivos de la creación cultural", disparó la conformación de un sistema autolegitimador que instituyó una dicotomía jerarquizada entre los 
civilizados "montaraces" de Medellín y los "otros", los "calentanos", enriquecida por imaginarios construidos por obra más del desconocimiento y temor a lo que eran y significaban las personas y las cosas de esa zona que del conocimiento real de sus pueblos, culturas y entorno natural. El secular aislamiento geográfico de esta subregión se va reempleando simbólicamente por el nuevo aislamiento de las valoraciones minimizadoras. La zona fronteriza entre el Aquí y el Allá volvió a quedar bien demarcada; las diferencias entre los habitantes de esos lugares y los de Medellín quedaron determinadas por el grado de civilización, de cohesión social y desarrollo que tenían.

"[...] Todo marcador de límites y toda muralla tienden a convertirse en una sacralización de lo propio y en un exorcismo de lo otro y del Otro. El Hombre está marcado al fuego por la frontera; la tensión del límite y la separación condicionan nuestro modo de ser y de existir; después de todo, cada sociedad, cada cultura y cada lengua se rodea, por el mero hecho de estar ahí y de ser lo que es, de una muralla nada fácil de penetrar" (Tolosana, C. 1994: 85 p).

Por razón del proyecto empresarial ferrocarrilero antioqueño, las fronteras entre la región montañosa y las cálidas y bajas regiones del Nus fueron efectivamente traspasadas, pero esta intromisión de los unos en el territorio de los otros, se hizo asumiéndose como la entrada de una "raza superior", en un territorio habitado por otra que le era inferior; como si fuera el otorgamiento y la difusión, realizados en las oscuras tierras de los pobres y de los ignorantes, de la luz de la civilización y de la razón; en fin, como significando la transformación de los zafios calentanos nativos en hombres dignos, a pesar suyo, de un Estado como el que habitaban. Así, de nuevo, y por virtud de la apertura de una nueva zona de "colonización" cultural (en realidad un extenso, fértil y no roturado territorio que se ofrecía como un prometedor espacio de jugosos emprendimientos capitalistas al cual, por antioqueños, tenían derecho también), se ofreció a la élite montaraz el despliegue y la instauración de manera dominante de las intachables virtudes del ser antioqueño.

\section{Malvivientes y Malentretenidos: Los Habitantes del Nus}

Hasta finales de los sesenta del Siglo XIX, la zona del Nus estaba poco poblada y para los intereses y en las imágenes de la clase empresarial, de los gobernantes y de la "buena sociedad" de Medellín, era en la práctica inexistente. Su interés por ese lugar había sido hasta entonces nulo, percibida sólo como una fracción del territorio del Estado poco atractiva e inútil para el desarrollo. No hubo autoridades que representaran los intereses de Antioquia allí; no había un gran control 
institucional, pocos representantes de las autoridades civiles, de la policía o de la Iglesia. Allí arribaba quien quisiera, sin necesidad de explicar de dónde venía y bajo qué tipo de condiciones. Las personas eran libres de hacer y de vivir como mejor les pareciera.

Así, con el tiempo esta región se convirtió en refugio de los más diversos tipos de inmigrantes venidos por múltiples razones de otras regiones del territorio nacional. Algunos de ellos eran indígenas descendientes de los originales habitantes de la zona o que habían llegado de otros lugares huyendo de los malos tratos y del servilismo, pero en su mayoría los pobladores eran o descendían de los negros cimarrones desertores del régimen esclavista de la costa Atlántica y de las minas de Remedios y Segovia en Antioquia. También había mestizos, pequeños agricultores o pescadores, así como vagos, prostitutas o ladrones que llegaban de cualquier parte del Estado o de las territorios limítrofes como Santander.

Esta variadísima conformación étnica, social y cultural de los habitantes del Nus no permitió que se consolidara un proceso de concertación homogeneizadora entre los diversos grupos sociales colonizadores, que permitiera la construcción de un orden que rigiera la convivencia y la organización de sus habitantes. Se formaron, más bien, distintos núcleos grupales que asumieron sus particulares reglas sociales y que siguieron viviendo según los patrones y los estilos consuetudinarios que traían consigo desde sus lugares de origen. Este hecho, por una parte, hizo prácticamente imposible, cualquier proceso de cohesión social en la subregión que tal vez les hubiera permitido sobreponerse al aislamiento y a la marginación que marcaba seguramente sus historias desde antes de salir del lugar de donde emigraron. Pero, del otro lado, ese "sentido de exclusión fue formando en los pobladores [...] mentalidades distintas, sentidos comunes y prácticas culturales diversas; interiorizaron y reprodujeron la exclusión, asumieron la diferencia impuesta como principio de la propia identidad y terminaron por pensarse a sí mismos como los otros, expresándose a través de formas culturales de resistencia y supervivencia" (Uribe, M.T. 1997: 8 p).

Estas formas de resistencia crearon -visto el proceso ahora desde el lugar de los "calentanos"-, por sobre las diferencias, una contraposición entre los pobladores de la región y las elites montaraces, lo que contribuyó a reforzar, dentro de la mirada segregacionista de éstas últimas, su aprendida comprensión colonialista europeizante de lo europeo frente a lo americano, que postulaba que los hombres de América debían en parte su menor inteligencia, su incivilización y su mal predisposición general, al hecho de vivir en climas tropicales no aptos para el desarrollo de las cualidades necesarias para el progreso del ser humano. 
Las élites montaraces aprovecharon las características climáticas, geográficas y naturales de la capital del Estado, para antagonizar el clima templado, las montañas y el predominio en ellas del hombre sobre la naturaleza con el clima cálido, las llanuras ribereñas y la supremacía de la naturaleza, entendida ausencia de civilización, de la región del Nus y, así, poder juzgar a aquellas tierras y a aquellas gentes como seres carentes de luces, reducidos física y mentalmente.

Los habitantes del Nus llegaron a convertirse, por obra de esta efectiva funcionalización de imaginarios hegemónicos, con ocasión del cruce de fronteras, en seres no sólo distanciados del desarrollo material de Antioquia, sino, en rigor, alejados del ideal del ser antioqueño, afectados por entorno salvaje no domeñado, que los tornaba en seres improductivos, ociosos y viciosos. Postulaba este ideario del hombre diferente, que los habitantes del Nus eran personas que desde pequeñas ya estaban determinadas por ese estilo estéril de vida, por lo que, llegados a la juventud, se volvían personas sin iniciativas, en seres material y espiritualmente ociosos y sedentarios. Desde Medellín se les aplicaba a éstos el refrán de que "la ociosidad era la madre de todos lo vicios y desórdenes" y, que por tanto, había que buscarla manera de erradicarla de allí o bien reconducirla, haciendo de estos hombres y mujeres personas de bien.

Entre todas las caracterizaciones deslegitimadoras de la sociedad encontradas al paso del ferrocarril por la región del Nus, Medellín percibió un gran riesgo cultural y social en el hecho de postular a los habitantes de esta región como idólatras, supersticiosos y descreídos, que no seguían las leyes de la Iglesia católica ni, por tanto, las escasas enseñanzas cristianas de los casi inexistentes sacerdotes que se arriesgaban a pasar por allí en plan misionero. Afirmaban los de Medellín que los del Nus no aceptaban a los curas como sus guías espirituales, que vivían en concubinato, que entre ellos no existía el matrimonio, ni el bautizo para sus hijos y mucho menos el pago de los diezmos, y que, lo peor de todo, tenían devociones míticas y creencias en poderes sobrenaturales alejados de la fe en el Dios verdadero.

Esta forma de vida se debía, según los dirigentes antioqueños, a que "sus actos antes que una labor de razonamiento, obedecían apenas a un comportamiento instintivo. Nada bueno podía surgir de él, pues el clima tropical lo había hecho tan degenerado que el hombre [...] tenía opacados incluso las motivaciones mas básicas que construían la vida social [...]" (Peralta, J. 1998: 20 p). En fin, los habitantes de esta zona tropical se encontraban, en una especie de atávico estado prerracional -dicho en términos hegelianos- es decir, que su comportamiento respondía sólo a las necesidades básicas que su cuerpo les urgía, pero no a la 
conducción de su capacidad de razonamiento inteligente. Fueron calificados los habitantes del Nus como nido de malvivientes, prostitutas y vagos, lo que hacía a la región controversial y difícil de manejar. Según, Mr. Gélineau, refiriéndose a los habitantes de las tierras calentanas "el hombre es miserable en esa naturaleza. Bronceada la tez y ennegrecida por el sol, dominado por clima enervante, es inhábil para los trabajos de entendimiento, porque la región del sol no puede ser el país de la actividad ni de la Inteligencia" (Uribe, M. 1888).

Visto desde la perspectiva del habitante del Nus, la diferenciación hegemónica de los montaraces radicaba simplemente en que sus pretensiones se alejaban de las ambiciones mercantiles y de prestigio que caracterizaban acicateando la vida cotidiana de los montaraces, y más bien se centraban en la búsqueda de una vida independiente y autosuficiente en medio de las dificultades del entorno, a un ritmo, un modo y un sentido no compartido con la visión ni las expectativas de los empresarios que irrumpen en la vida de la región con ocasión del avance de la línea férrea. Sin embargo, el encuentro se hizo choque al momento en que se hizo necesario vincular la mano de obra de la región al adelanto del proyecto ferrocarrilero.

Este panorama fue el que encontraron los iniciadores del ferrocarril cuando llegaron al Nus. Un reducido número de pobladores, todos ellos con la convicción de vivir al borde de las reglas, por fuera de las leyes y normas generales de convivencia establecidas para otros ámbitos. Estas gentes, gracias al histórico aislamiento en que habían vivido, habían logrado construir espacios sociales determinados por la autonomía material y la independencia social; dueñas, en cierto sentido, en su aislamiento autosuficiente, de su precario pero, hasta aquel momento, propio destino. Estos eran, pues, los rurales, hombres peligrosos de las fronteras cálidas de Antioquia, aquéllos que no acataban la vida civilizada de las ciudades.

Este encuentro dio lugar, pues, a una conflictiva relación centro-periferia, en donde se diferenciaba nítidamente al habitante de Medellín culto, civilizado, vigoroso y emprendedor, de ese otro.

"habitante de las orillas del Magdalena, [que] acostado en su hamaca, pasa largas horas al día perezoso y soñoliento. Al sentirse aguijoneado por el hambre, arroja al río el chinchorro y se procura un rico alimento: en el patio crecen espontáneamente el pimiento y el ají. Con el guarapo, néctar para el calentano, y el plátano, ambrosía para todo el mundo, completa un festín que ni siquiera han soñado los proletarios de Europa. Pero esa vida fácil, abundante, perezosa, 
enervó sus facultades, lo embrutece y lo degrada. Nace, vegeta y muere y pasa por la vida sin dejar huella ninguna, como los cuadrúpedos en sus bosques"

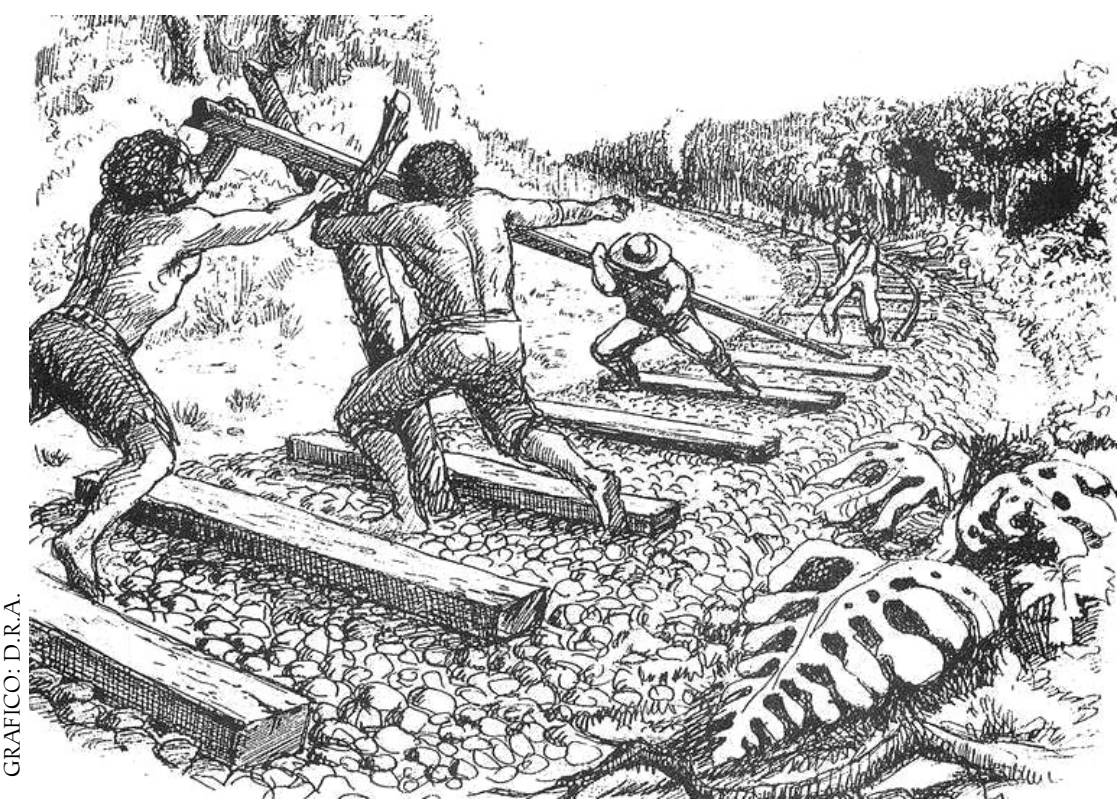

(Cisneros, F.J. 1880: 141 p).

Medellín y sus habitantes, modelos a seguir, por sus costumbres, su desarrollo, su organización y sus instituciones, de imágenes culturales, se constituyeron en patrón y estrategia de un proyecto civilizatorio de hegemonía que corrió parejas con el avance de los rieles de acero. La diferencia generó la necesidad de la igualación. La transformación de esa gentes se convirtió en una imperiosa necesidad, si se quería realizar con éxito el proyecto empresarial que daba sentido, contexto y motivaba la construcción del tramo ferrocarrilero. Era necesario describir y clasificar todo lo que en esta región había, y a partir de ello, catalogar y estructurar la erección de un mundo nuevo, acorde con el gran proyecto civilizatorio en marcha, adecuado a una región que sería lugar de tránsito de la obra más importante de Antioquia, el Ferrocarril. Con esta perspectiva, se establecieron una serie de cambios civilizatorios para las personas que allí habitaban.

Una de ellos, fue declarar al territorio del Nus como espacio de colonización o "vacío", como los llama Fernán González (1997), es decir, lugares que no estaban oficialmente comprometidos, de manera que sus tierras podían ser redistribuidas entre nuevos propietarios sin importar quién estuviera asentado en ellas. Esto fue fácil hacerlo, ya que la población de la zona no estaba sujeta a un lugar específico, no había estructurado poblados, y se establecía en un lugar sin considerarlo como definitivo o temporal. Además de ello, se decretaron leyes como la de vagancia o las restricciones para el voto mediadas por títulos de propiedad que impedían a los ya habitantes del Nus reclamar sus tierras y sus derechos.

Con estas medidas, las élites esperaban la transformación civilizatoria de la población, lo que implicaba que ella saldría del "bosque espeso y bravío, en que se distinguían apenas las fieras, a las suntuosas ciudades en que florecen las 
ciencias y las artes, en que dominan la inteligencia y la cultura, en que la justicia tiene sujeta la violencia, la razón domina á la fuerza, la virtud tiene su culto, la execración reprime los vicios, la riqueza y bienestar crecen y se extienden con pasmosa rapidez" (Ospina, M. 1884: 7 p).

Fue así, con esta perspectiva, con la que los fundadores del Ferrocarril de Antioquia iniciaron su proceso de acercamiento a la zona del Nus. Buscaron a toda costa

"sembrar la simiente que ha de producir el abundante fruto que ha de convertirse para nuestros hijos en pan, industria, holgura, en el ansiado bienestar; se trata de poner a la generación que nos suceda en actitud de presentarse con dignidad ante un mundo inteligente y sabio, salida ya de la crisálida del salvaje y en capacidad de ostentar con satisfacción y orgullo su abolengo; se quiere que nuestros hijos tengan medios para vencer seguramente la miseria y la ignorancia" (Junta del Ferrocarril de Antioquia, 1896: 372 - 373 p).

De esta manera, hemos podido percibir algunas líneas principales del proceso de recolonización empresarial de la región del Nus, que generó un particular proceso de dominación/resistencia, asumida en los imaginarios del empresariado y la dirigencia antioqueña como un episodio específico de esa universal e irreconciliable confrontación (tan socorrida visión de las élites republicanas decimonónicas hispanoamericanas) entre civilización y barbarie. Gracias a este caso particular, podemos apreciar algunos postulados fundamentales de la ideología expansionista de las élites antioqueñas en el tránsito del siglo XIX al XX. La ideología de un proyecto de desarrollo hegemónico que proponía un sistema de imágenes centradas en el progreso entendido como "adelantamiento", como "avance", tan irrefrenable como universal, que debía incluir, por la persuasión o la coerción, a todos los habitantes de Antioquia, pagando el precio que hubiere que pagar por ello, a fin de conformar una saludable sociedad homogénea y militante de ciudadanos limpios, honrados, laboriosos, e incluso ilustrados. Los postulados principales de este proyecto e ideario no dejan de percibirse hoy día en los imaginarios y la cotidianidad del hombre antioqueño del presente.

\section{BIBLIOGRAFÍA}

AINSA, Fernando. La frontera como límite protector de diferencias y como espacio de encuentro y transgresión. En: Boletín de la Academia Nacional de Letras. Montevideo, No 7, Enero-julio de 2000. 
BERGALLI, Roberto y MARI, Enrique E. (coordinadores). Historia ideológica del control social (España - Argentina, siglo XIX y XX). Promociones y publicaciones universitarias, S.A., Barcelona. 1989.

CHARTIER, Roger. El mundo como representación. Historia cultural en práctica y representación. Edición Gedisa, Barcelona. 1995.

CISNEROS, Francisco Javier. Memorias sobre la construcción de un Ferro-carril de Puerto Berrío a Barbosa (Estado de Antioquia). Imprenta y Librería de N. Ponce de León, Nueva York. 1880.

ELÍAS, Norbert. «El proceso de la civilización. Investigaciones sociogenéticas y paragenéticas». México, Fondo de Cultura Económico. 1987.

Santafé de Bogotá. 1998.

"La civilización de los padres y otros ensayos». Editorial Norma,

ESCOBAR, Edgar G. Un gran trabajo obrero. Colección Academia Antioqueña de Historia, Medellín. 1975.

GONZÁLEZ G, Fernán. Para leer la política. Ensayos de Historia de Colombia. CINEP, Santafé de Bogotá. 1997.

Instituto Geográfico Agustín Codazzi. Monografía del Departamento de Antioquia. Citado por: Bravo B, José María. Monografía sobre el Ferrocarril de Antioquia. Ediciones Autores Antioqueños, Medellín. 1993.

Junta Consultiva del Ferrocarril. Informe. En: Periódico del ferrocarril de Antioquia. Medellín, No 52. Julio 27 de 1896.

JURADO, Juan Carlos. Los caminos. Mimeo, Medellín. 1999.

KASTOS, Emiro. Artículos escogidos (1859). Biblioteca Banco Popular, Bogotá. 1972.

LÓPEZ B, Olga del Pilar. Las tres fiebres: tres discursos, tres cuerpos, tres maneras de enfermarse. (Tres espacios, tres tiempos: finales del siglo XIX, principios del siglo XX y finales del siglo XX). Tesis. Universidad Nacional de Colombia, Medellín. 1998.

OSPINA R, Mariano. La Civilización. En: Molina, Juan José. Artículos escogidos del Doctor Mariano Ospina. Imprenta republicana, Medellín. 1884.

PERALTA, Jaime Andrés. Climas cálidos, hombres degenerados y espíritus corrompidos. La ilustración frente a la diversidad cultural de la Nueva Granada. Medellín, mimeo. 1998.

PERALTA, Jaime Andrés. Selva, riqueza y barbarie; el chocó imaginado por la colonización antioqueña. Apuntes para una historia cultural de las relaciones interétnicas en el noroccidente colombiano (1830-1930). En: Revista Utopía Siglo XXI. Universidad de Antioquia, Medellín. Volumen 1, No. 3, enero- junio de 1998.

TOLOSANA, Carmelo. Antropología de la frontera. En: Revista de Antropología Social, número3. Editorial Complutense, Madrid, 1994.

TWINAM, Ann. Mineros. Comerciantes y labradores: las raíces del espíritu empresarial en Antioquia: 1763-1810. Fondo Rotatorio de Publicaciones FAES, Medellín. 1985. 
URIBE, M, Francisco A. Comentario del artículo publicado en La Médecine Hypodermique del primero de octubre de 1888. En: Revista Anales de la Academia de Medicina. Medellín. V1, No 10, 1888.

URIBE, María Teresa. Citada por: Alonso, Manuel Alberto. Conflicto armado y configuración regional. El caso del Magdalena Medio. Editorial Universidad de Antioquia, Medellín. 1997

\section{BIOGRAFÍA}

\section{MARGARITA ROSA DÍAZ BENJUMEA}

Comunicadora Social - Periodista, Especialista en Animación Sociocultural y Pedagogía Social, Magíster en Salud Pública. Investigadora, vinculada al Centro de Investigaciones de la Universidad de San Buenaventura - Cartagena. 